\title{
Influence of wave-induced disturbance on seasonal spawning patterns in the sabellariid polychaete Phragmatopoma lapidosa
}

\author{
Daniel A. McCarthy ${ }^{1,2, *}$, Craig M. Young ${ }^{1}$, Roland H. Emson ${ }^{2}$ \\ ${ }^{1}$ Department of Larval Ecology, Harbor Branch Oceanographic Institute, 5600 North, Fort Pierce, Florida 34946, USA \\ ${ }^{2}$ Division of Life Sciences, King's College, University of London, 150 Stamford Street, London SE1 9NN, United Kingdom \\ ${ }^{3}$ Present address: Smithsonian Marine Station at Fort Pierce, 701 Seaway Drive, Fort Pierce, Florida 34949-3140, USA
}

\begin{abstract}
The effect of wave-induced disturbance on seasonal spawning patterns of the opportunistic polychaete Phragmatopoma lapidosa (Kinberg, 1867) was investigated by comparing seasonal fecundity, egg size and adult size between intertidal and subtidal worms at Boynton Beach, Florida. Fecundity patterns showed spawning peaks in summer and fall in both habitats, with reduced spawning in late fall and early winter. Subtidal females averaged 1015.2 eggs $\mathrm{mm}^{-1}$ body length (range 0 to 2000 eggs $\mathrm{mm}^{-1}$ ), while intertidal females averaged 607.4 eggs $\mathrm{mm}^{-1}$ (range 0 to 1520 eggs $\mathrm{mm}^{-1}$ ). Mean egg diameters were not significantly different between worms from the 2 habitats, ranging between $90.4 \mu \mathrm{m}(\mathrm{SD}=3.7)$ and $89.5 \mu \mathrm{m}(\mathrm{SD}=4.3)$ for intertidal and subtidal worms respectively. Inter- and intra-census comparisons of egg diameter, fecundity and adult length revealed few statistically significant relationships, suggesting that intertidal and subtidal worms were the same age. Adult lengths in both habitats did change seasonally. The smallest adult worms were found shortly after massive fall recruitment replaced a large percentage of individuals in both intertidal and subtidal populations. Stepwise multiple regression indicated that $76.2 \%$ of the variance in intertidal fecundity was explained by a negative correlation with wave height $(40.4 \%)$, and a positive correlation with day length $(34.7 \%)$. In contrast, $85.5 \%$ of the variance in subtidal fecundity was explained by a positive correlation with day length $(77.4 \%)$, and a negative correlation with chlorophyll a concentration $(8.1 \%)$. While habitat-specific differences in energy available for gametogenesis probably contribute towards the observed fecundity trends, the force of crashing waves could also influence fecundity, as it may affect frequency of spawning in intertidal but not subtidal habitats.
\end{abstract}

KEY WORDS: Phragmatopoma $\cdot$ Polychaetes $\cdot$ Fecundity $\cdot$ Spawning $\cdot$ Reproductive plasticity

\section{INTRODUCTION}

Predictable and unpredictable disturbances in natural communities are known to be important in shaping the life-history patterns of both terrestrial and aquatic species (Pickett \& White 1985, Hildrew et al. 1994). Space is often at a premium for sedentary animals and disturbance creates space for colonization by new individuals in otherwise crowded habitats (Osman 1977, Sousa 1984, Connell \& Keough 1985). Opportunistic species can take advantage of sudden avail- ability of space because they have the ability to reproduce quickly in response to a disturbance event. Thus, disturbance may in theory provide space for colonization while simultaneously cueing a reproductive response that permits the occupation of that new space.

Few studies of marine invertebrates have quantitatively demonstrated a tight link between seasonal disturbances that create space for settlement and reproductive responses of species that take advantage of the newly opened space (Barry 1989). Several correlative 
studies on marine invertebrates have attempted to relate reproductive responses to external stress factors such as sedimentation, wave activity and turbidity (Rinkevich \& Loya 1979, Kojis \& Quinn 1984, Jokiel 1985, Tomascik \& Sander 1987, Szmant \& Gassman 1990, Van Veghel \& Bak 1993, Ward 1995, Cardenas \& Aranda 2000). These studies imply that disturbance affects rates of seasonal egg production or spawning.

Sublethal disturbance is known to affect reproductive output by diverting energy to regeneration of body parts, thereby reducing the energy available for reproduction (Lawrence \& Vasquez 1996). For example, polychaetes regenerating lost or damaged body parts have lower fecundity and longer time to maturity than their undamaged counterparts (Hill \& Grassle 1981, Hill et al. 1982, Zajac 1985).

Disturbance may also cue spawning of marine invertebrates. Stress caused by changes in water pressure, desiccation, temperature, wave action and salinity has been implicated in numerous studies as cueing spawning and/or gametogenic synchrony of populations of marine invertebrates, although quantitative documentation of the specific mechanisms involved are rare (see Giese \& Kanatani 1987 for review).

The sabellariid polychaete Phragmatopoma californica is one of the few known species where a disturbance mechanism facilitates spawning and also subsequent colonization (Taylor \& Littler 1982, Swarbrick 1984, Jensen 1986, Barry 1989). Barry (1989) documented recruitment peaks in $P$. californica several months after storms damaged reefs and created settlement space. He suggested that recruitment peaks resulted from spawning events that occurred during periods of increased wave activity that destroyed $P$. californica reefs. This conclusion was based on the knowledge that $P$. californica always carry eggs and are known to spawn gametes when they are removed from their tubes or agitated (Eckelbarger 1976, J. Pawlik pers. comm.). However, it was not known if recruits originated from disturbed adult colonies or from colonies that spawned elsewhere over the species range. Consequently, the environmental factor responsible for cueing spawning in the adults that produced the observed recruits was unknown.

Phragmatopoma lapidosa, possibly a conspecific of P. californica (Pawlik 1988) and/or a synonym of P. caudata (Kirtley 1994), is a reef-building polychaete with a geographic distribution from Brazil to southern Florida (Hartman 1944). Adults live mostly in the intertidal zone on hard bottoms (Hartman 1944, Eckelbarger 1976, Kirtley 1994) although they may occur subtidally down to $10 \mathrm{~m}$ (Kirtley 1994, McCarthy 2001). They exhibit opportunistic life-history characteristics such as fast growth, short time to sexual maturity, and a strong resilience toward the harsh physical disturbances that occur in their habitats (Eckelbarger 1976, 1979, Main \& Nelson 1988, Kirtley 1994). While Eckelbarger (1976) suggested that $P$. lapidosa have the ability to produce gametes throughout the year, the spawning pattern of any Florida $P$. lapidosa population remains unknown.

The goal of this study was to examine the role of wave energy in affecting seasonal spawning patterns in the sabellariid Phragmatopoma lapidosa. Seasonal counts of egg numbers were made for individual worms from intertidal and subtidal habitats. The number of eggs present in an individual sabellariid worm at any moment in time will reflect both egg production and frequency of spawning. Both of these factors may vary with season and also with the degree of disturbance in a particular habitat. In this study, we used Pearson correlations and stepwise regressions to determine relationships between intertidal and subtidal fecundity with seasonal environmental variables such as day length, sea temperature, chlorophyll a and wave height. Our objectives were to determine: (1) if there were seasonal differences in spawning between intertidal and subtidal worms, and (2) whether intertidal or subtidal spawning was more tightly linked to seasonal storm events that increase wave activity than to any of the other measured environmental factors.

\section{MATERIALS AND METHODS}

Study sites and sampling. Several clumps of Phragmatopoma lapidosa were collected every month from 4 intertidal and 4 subtidal sites off Boynton Beach, Florida (latitude $26^{\circ} 32.00^{\prime} \mathrm{N}$, longitude $80^{\circ} 2.50^{\prime} \mathrm{W}$ ) from June 1997 to January 2000 (Fig. 1). At each site, intertidal and subtidal sabellariids formed reef formations on natural limestone. Subtidal reefs were in $\sim 4 \mathrm{~m}$ depth, approximately $20 \mathrm{~m}$ offshore. Worm clumps were collected at the 2 habitats alternately, to reduce potential artifacts from holding worms in buckets for extended periods.

Seasonal data on several environmental factors were obtained to investigate potential relationships with measured life-history characteristics. Day-length, sea temperature and wave height data for the nearshore waters off east Florida were obtained from the US National Weather Service. Actual mean chlorophyll a values for a nearby site (Fowey Rocks, North Key Biscayne) were provided by the Southeast Environmental Research Center (Florida International University). Chlorophyll a values at Fowey Rocks may be representative of values at Boynton Beach because the Florida Current transports water between the 2 locations (96 km apart) very quickly. However, as an additional measure of chlorophyll $a$, satellite estimates (SeaWiFS) of chlorophyll $a$ in the Boynton Beach area were 


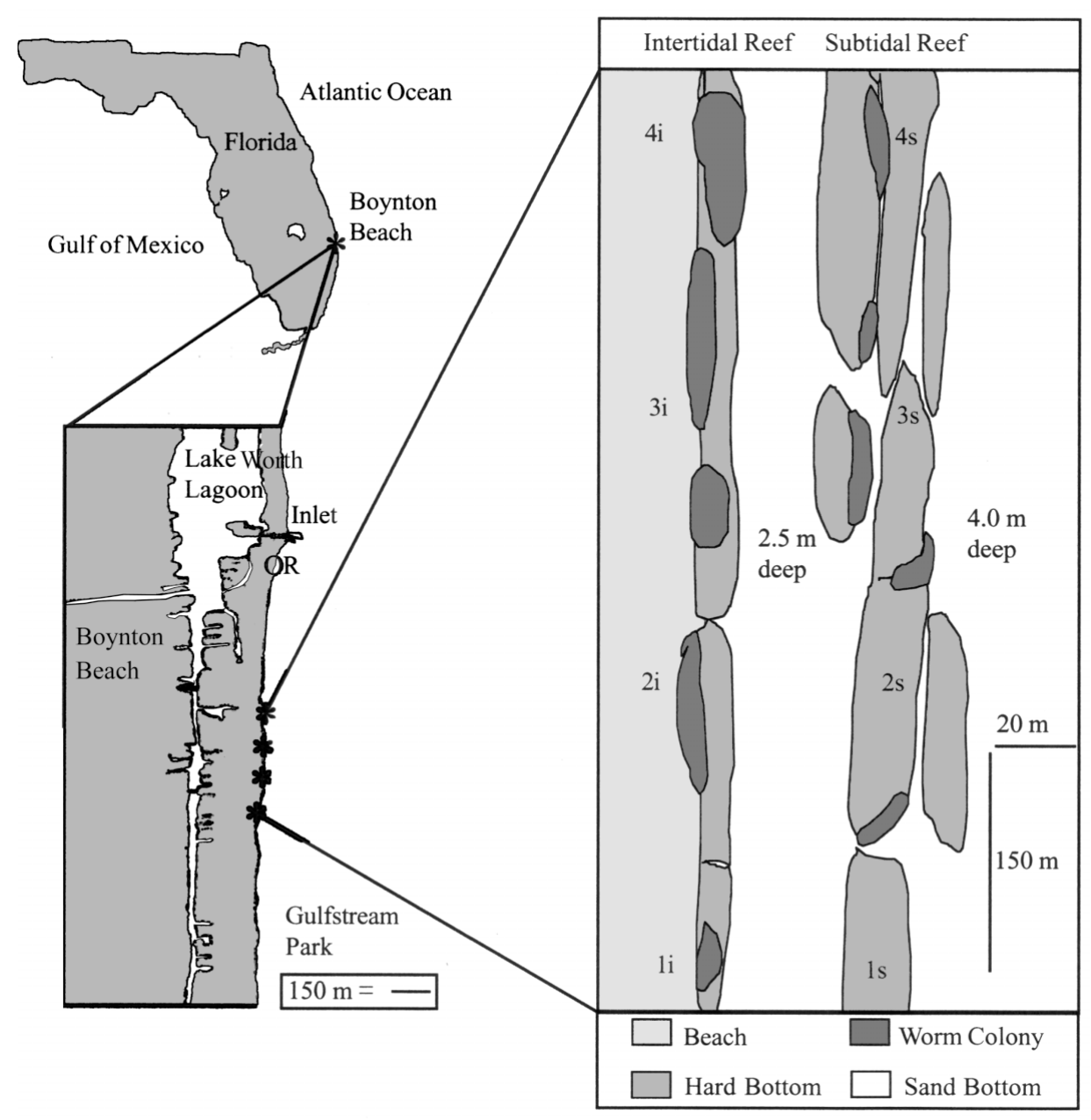

Fig. 1. Map of Florida showing Boynton Beach area. Inset shows close up of Boynton Beach, with number designations representing collecting sites (e.g. 1i = Site 1, intertidal). Clusters of Phragmatopoma lapidosa were collected from 4 intertidal and 4 subtidal sites. Subtidal habitats ( 4 m deep) were approximately $20 \mathrm{~m}$ from intertidal habitats. OR = Ocean Ridge beach restoration area

obtained from the University of South Florida. All daily values of each environmental factor were averaged for the time period ( 1 to $2 \mathrm{mo}$ ) preceding each sampling period.

Fecundity, egg diameter and adult size. In the laboratory, individuals of Phragmatopoma lapidosa from haphazardly chosen pieces of reef were removed from their tubes, and placed in finger bowls, which induced them to spawn immediately: 5 females were obtained from each site, giving a total of 20 worms from each habitat. Each worm was left in a bowl for $24 \mathrm{~h}$ to ensure complete spawning of eggs. Worms were then relaxed in a $0.36 \mathrm{M} \mathrm{MgCl}_{2}$ solution. The length of each worm was then measured from the posterior end of the collar to the end of the last segment. All spawned gametes were preserved in $5 \%$ formalin.

To test for egg-number and egg-size differences between intertidal and subtidal Phragmatopoma lapidosa, preserved eggs were allowed to settle in a petri dish scored with 95 quadrats of $25 \mathrm{~mm}^{2}$ each. Eggs in 50 of the quadrats were used to estimate the total number of eggs spawned. Fecundity values were standardized by dividing the number of eggs by the length of the worm; 50 eggs were then randomly chosen from each individual, and the area of each egg was measured with UTHSCSA Image Tool software (Wilcox et al. 1995). Egg areas were then converted to feret diameters, and averaged for each female.

Differences in the reproductive parameters of Phragmatopoma lapidosa between intertidal and subtidal sites were investigated using 2-way nested ANCOVAs (SYSTAT 1992). Fecundity, egg diameter and adult length were dependent variables, with habitat and month as the independent variables. Site was nested within habitat and adult length was used as a covariate. Tukey pairwise comparisons were used to compare levels of fecundity, egg size and adult size, for each habitat and time period (SYSTAT 1992). 
Statistical correlations and regressions. Potential relationships between measured life-history and reproductive characteristics of Phragmatopoma lapidosa were investigated for each habitat by statistical correlations using 2 types of data - inter- and intracensus. In both sets of correlations, individual mean values of fecundity, egg diameter and adult length were separately correlated with Pearson correlations for each habitat (SYSTAT 1992).

The relationships between several seasonal environmental factors and the measured life-history character-
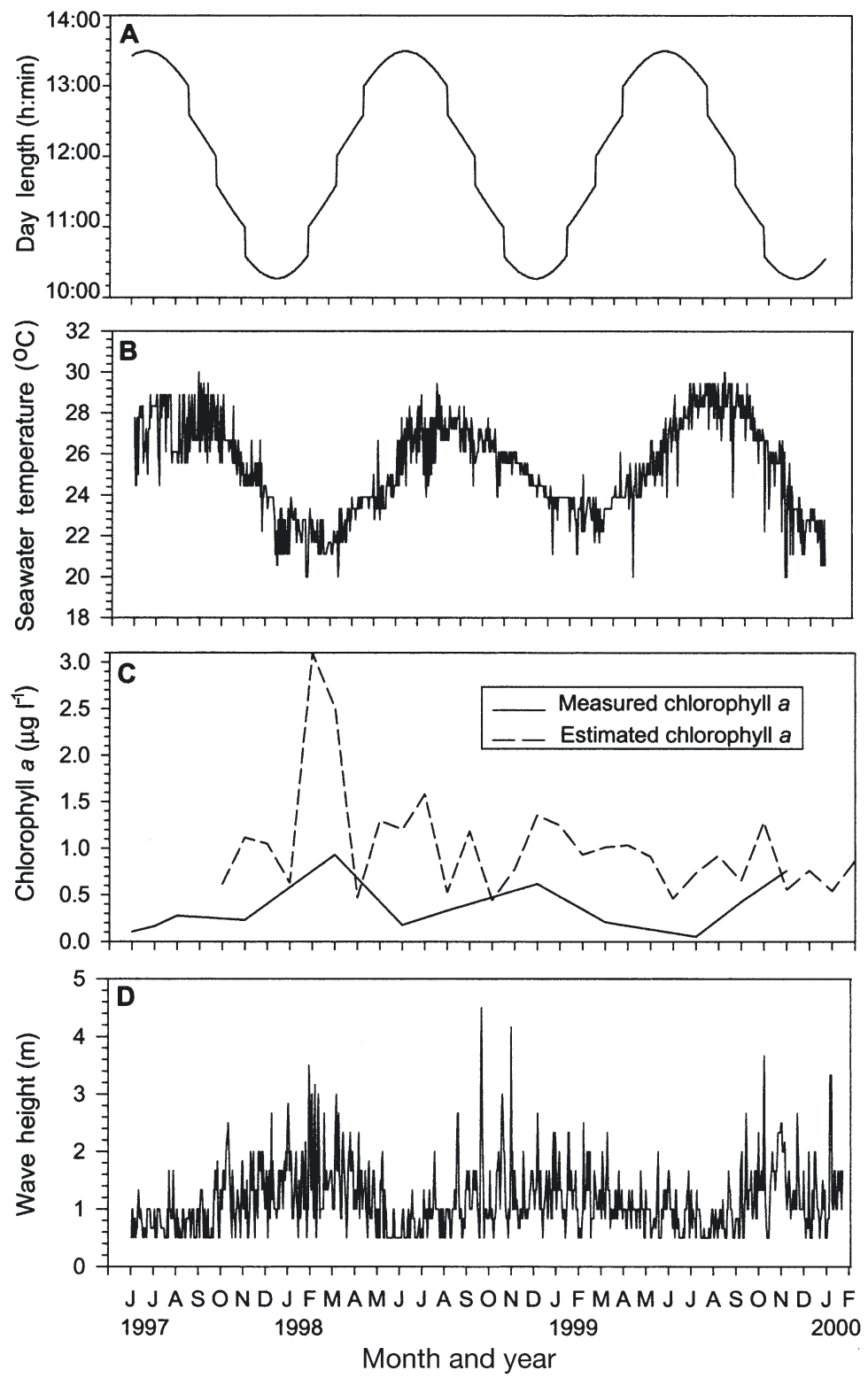

Fig. 2. Seasonal mean values of (A) day length, (B) seawater temperature, (C) chlorophyll $a$ and (D) wave height for the southeast Florida area. Measured and estimated chlorophyll a values are from Fowey Rocks and Boynton Beach respectively istics of Phragmatopoma lapidosa from intertidal and subtidal habitats were also investigated using statistical correlations. Mean values of each environmental factor were used in separate Pearson correlations with census means of fecundity, egg length and adult diameter for each habitat (SYSTAT 1992).

Stepwise multiple regression (linear fit) was used to determine which combination of environmental factors best accounts for the variation in fecundity, egg size and adult lengths (SYSTAT 1992). The relative importance of each environmental factor in affecting dependent factors was assessed by evaluation of the adjusted r-square value after its addition to a regression model.

\section{RESULTS}

\section{Study sites and sampling}

Statistical analyses of life-history characteristics were only carried out from June 1997 through March 1999 because of the negative effects of a neighboring beach restoration project. In spring 1998, $783000 \mathrm{~m}^{3}$ of offshore sand were deposited at Ocean Ridge Beach (1.6 to $2.4 \mathrm{~km}$ north of the study sites). During subsequent collections at Boynton Beach, it was observed that gray restoration sand had been transported south, affecting the subtidal sites and covering a significant amount of the hardbottom/worm reef habitat. Subtidal collections ceased in June 1999 because no live worms could be found in the diminishing habitat, although the worm mounds were still present. By August 1999 there was minimal hard-bottom habitat, and no visible worm mounds were exposed in the subtidal study area. Consequently, statistical comparisons between life-history characteristics of intertidal and subtidal individuals were only possible for collections made during 22 of the 32 months of the study.

Day length and seawater temperature exhibited low inter-annual variability (Fig. 2A,B), while chlorophyll $a$ and wave height were generally more variable (Fig. 2C,D). Maximum daylight hours of approximately $13.5 \mathrm{~h}$ were from June through August, and minimum daylight hours of approximately $10.5 \mathrm{~h}$ from December through January (Fig. 2A). Seawater temperatures varied seasonally, with high values ranging between 25.6 and $30.0^{\circ} \mathrm{C}$ between July and October and low values ranging between 20.0 and $23.3^{\circ} \mathrm{C}$ from January to April (Fig. 2B). 
A positive correlation $(\mathrm{r}=0.521)$ was found between Fowey Rocks chlorophyll a measurements and Boynton Beach chlorophyll a estimates. Seasonal peaks in chlorophyll a values at Fowey Rocks were between 0.600 and $0.875 \mu \mathrm{g} \mathrm{l^{-1 }}$ and occurred during late fall and early winter. Satellite estimates for Boynton Beach were higher, ranging between 1.100 and $3.097 \mu g \mathrm{l}^{-1}$, with peaks during late fall, early summer and early winter. Low values of chlorophyll $a$ at Fowey Rocks were between 0.050 and $0.175 \mu g \mathrm{l}^{-1}$ and occurred during late spring and summer (Fig. 2C). Low values at Boynton Beach were between 0.446 and $0.629 \mu \mathrm{g} \mathrm{l}^{-1}$ and occurred mostly during late summer and fall.

Increased wave activity occurred from October 1997 to May 1998, July 1998 to May 1999 and September 1999 to February 2000 (Fig. 2D). The highest values were recorded in February and March 1998 (3.0 to $3.7 \mathrm{~m}$ ), October and November 1998 (4.0 to $4.3 \mathrm{~m})$, October 1999 (2.7 to $3.7 \mathrm{~m}$ ) and January 2000 (1.7 to $3.3 \mathrm{~m}$ ). The calmest periods of the study were in the summer, from May to August, with mean values ranging between 0.5 and $2.0 \mathrm{~m}$.

\section{Fecundity, egg diameter and adult size}

The log-transformed fecundity values were significantly different between females from the 2 habitats (Table 1). Subtidal females averaged 1015.2 eggs $\mathrm{mm}^{-1}$ (SD = 1209.8), while intertidal females averaged 607.4 eggs $\mathrm{mm}^{-1}(\mathrm{SD}=717.1)$ (Fig. 3A). Within each site, except for Site 3, intertidal worms had significantly fewer eggs than subtidal worms (Fig. 3A). Adult size was not significant as a covariate in the analysis (Table 1).

Egg number fluctuated in a similar manner in both habitats through the year for Phragmatopoma lapidosa, although fecundity was often higher subtidally than intertidally (Fig. 4A,B). Generally standardized fecundity was highest in late spring and summer with means between 700 and 2000 eggs $\mathrm{mm}^{-1}$ (i.e. 17500 and 50000 total fecundity for a $25 \mathrm{~mm}$ worm, respectively). Fecundity was lowest in fall and early winter, with means between 0 and 575 eggs per mm (0 and 14375 total fecundity for a $25 \mathrm{~mm}$ worm).
Subtidal worms had significantly (Tukey pairwise probability $=0.05$ ) higher numbers of eggs than intertidal worms in October 1997, May 1998, November 1998 and March 1999 (Fig. 4A,B). Although not significant, the trend continued, with 6 additional months (June 1997, September 1997, December 1998, February 1998, April 1998 and March 1999) displaying higher subtidal than intertidal means of fecundity (Fig. 4A,B).

There were no habitat differences between logtransformed mean egg sizes of Phragmatopoma lapidosa. Mean egg sizes were $90.4 \mu \mathrm{m}(\mathrm{SD}=3.7)$ and $89.5 \mu \mathrm{m}(\mathrm{SD}=6.9)$ for intertidal and subtidal worms respectively (Fig. 3B). Egg diameter did not covary with adult size nor were there any site differences. Seasonally, egg diameters were largest in the fall and winter, with peaks in December 1997, February 1998 and March 1999. Egg diameters were smallest in summer and early fall, with lowest values in July 1997, July 1998 and November 1998 (Fig. 4C,D, Table 1). Egg diameters were significantly larger subtidally than intertidally in the month of July 1997 (Fig. 4C,D).

High seasonal variability in adult size was characteristic of both intertidal and subtidal Phragmatopoma lapidosa. Female P. lapidosa were similar sized with intertidal and subtidal lengths averaging $23.6 \mathrm{~mm}$ 
$(\mathrm{SD}=4.10)$ and $22.9 \mathrm{~mm}(\mathrm{SD}=4.11)$ respectively (Fig. 3C). Seasonally, the mean length of $P$. lapidosa changed similarly in both habitats (Fig. 4E,F, Table 1). However, adults were significantly larger intertidally than subtidally in July 1998 (Fig. 4E,F). The largest individual worms were obtained in late spring and through the summer, with lengths varying between 26 and $32 \mathrm{~mm}$. The smallest worms were measured in late fall and early winter, and ranged from 15 to $20 \mathrm{~mm}$ in length.
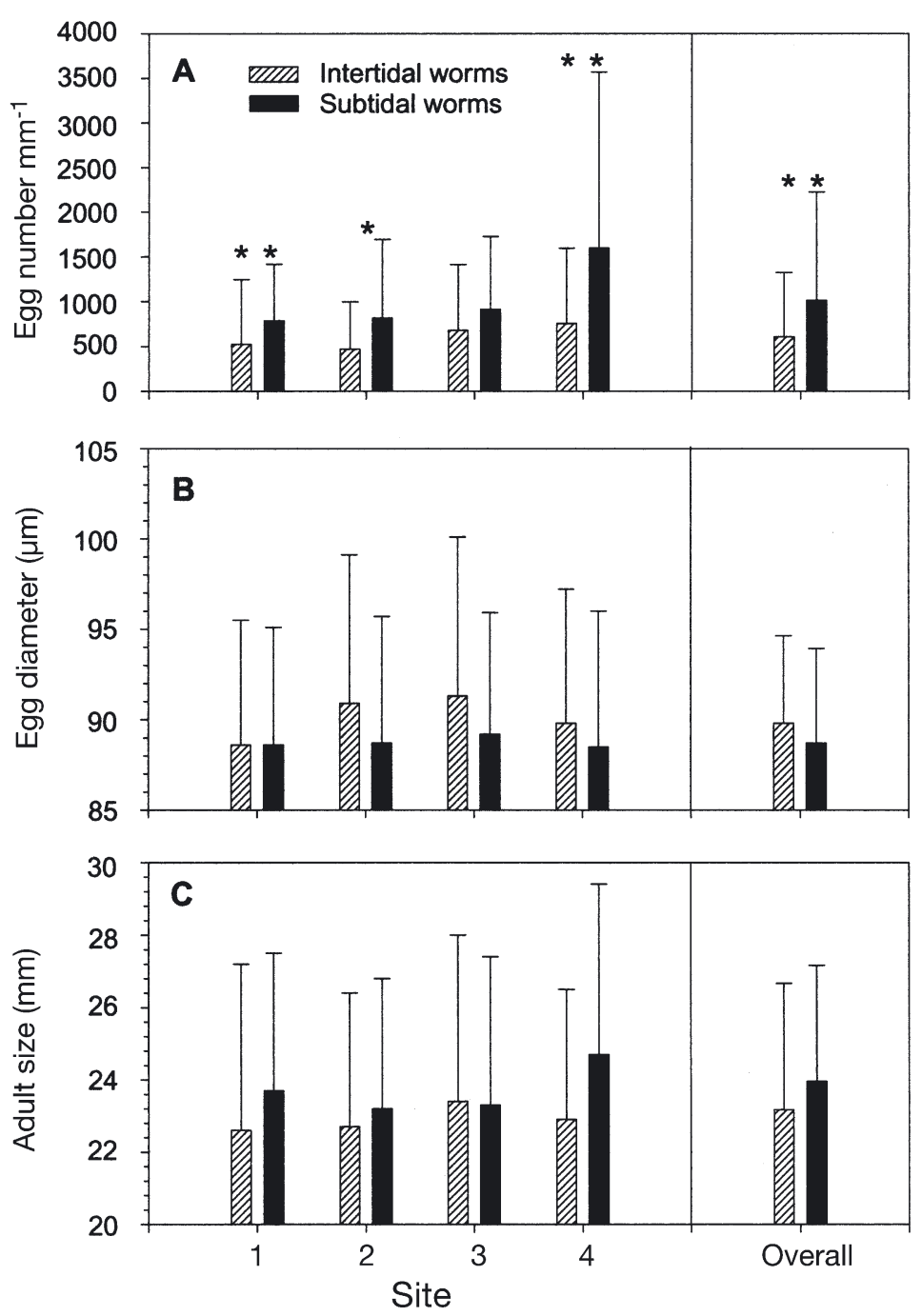

Fig. 3. Phragmatopoma lapidosa. Site and overall mean $( \pm 1.0$ SD) fecundity, egg diameter and adult length at 4 intertidal and 4 subtidal sites; $\mathrm{n}=70$ in all cases. (A) Fecundity: subtidal worms were significantly more fecund than intertidal worms $(\mathrm{p}<0.001)$; within each site, except for Site 3, intertidal (i) worms had fewer eggs than subtidal (s) worms (Tukey pairwise probablities between sites: $1 \mathrm{i}$ and $1 \mathrm{~s}=0.001,2 \mathrm{i}$ and $2 \mathrm{~s}=$ $0.008,3 \mathrm{i}$ and $3 \mathrm{~s}=0.983,4 \mathrm{i}$ and $4 \mathrm{~s}=0.001)$. (B) Egg diameters: no significant differences were found among site and habitat treatments. (C) Adult lengths: no significant differences were found among habitat site and treatments. Asterisks indicate significant difference between treatment means $\left(*: \mathrm{p}<0.01_{;} * *: \mathrm{p}<0.001\right)$

\section{Statistical correlations and regressions}

The majority of within-census correlations between egg diameter and egg number, and between egg diameter and adult length of Phragmatopoma lapidosa were not significant. Positive correlations were found between mean egg diameter and egg number in intertidal worms during December 1997 and March 1999 (Table 2). A negative correlation was found between egg diameter and mean egg number for intertidal worms collected in January 1999 (Table 2). Egg number was negatively correlated with adult length in intertidal worms obtained in January 1999 and positively correlated for subtidal worms collected in March 1998 (Table 2). Adult length correlated positively with intertidal egg diameter in March 1999 (Table 2).

There was only 1 significant seasonal correlation involving the measured life-history characteristics of Phragmatopoma lapidosa (Table 2). Egg number was positively correlated with adult length for intertidal worms (Table 2). All other correlations were nonsignificant.

Several significant correlations were found between mean fecundity, egg diameter and adult length and the observed environmental factors. Intertidal fecundity was negatively correlated with wave height and positively correlated with day length (Table 3). In contrast, subtidal fecundity was not significantly correlated with any environmental factor (Table 3). Both intertidal and subtidal egg diameter correlated only with sea temperature (Table 3). Adult size correlated positively with day length for both intertidal and subtidal worms (Table 3), and negatively with wave height for intertidal worms alone (Table 3). We also ran additional correlations incorporating 1 to 2 month lags of the environmental factors. However, none of these analyses revealed new trends among the measured life-history characteristics and environmental factors.

The stepwise regression analyses accounted for fairly high percentages of the variation in several of the dependent factors. Regression analysis revealed that $76.2 \%$ of the variance in intertidal fecundity $(F=27.7$; df $=2,16$; $\mathrm{p}<0.001$ ) was explained by a negative correlation with wave height $(40.4 \%$; p < 0.001), and a positive correlation with day length $(34.7 \% ; \mathrm{p}<0.001)$. In contrast, $85.5 \%$ of the variance in subtidal fecundity $(F=21.1$; df $=$ 
$2,16 ; \mathrm{p}<0.001)$ was explained by a positive correlation with day length $(77.4 \% ; \mathrm{p}<0.004)$, and a negative correlation with chlorophyll a $(8.1 \% ; \mathrm{p}<0.398)$. For egg size, $37 \%$ of the intertidal $(F=10.3 ; \mathrm{df}=1,15 ; \mathrm{p}<0.005)$ and $49 \%$ of the subtidal $(F=13.5 ; \mathrm{df}=1,12 ; \mathrm{p}<0.03)$ variance was explained by a negative correlation with seawater temperature at $\mathrm{p}$ values of 0.05 and 0.001 respectively. The analyses also revealed that $64.4 \%$ of intertidal adult length variance $(F=17.3$; df $=2,17$; $<<$ 0.001 ) was explained by positive relationships with day length $(59.0 \% ; \mathrm{p}<0.001)$ and sea temperature $(5.4 \%$; $\mathrm{p}<0.08)$. Subtidally, $83.3 \%$ of the adult length variance $(F=24.3$; df $=3,11 ; \mathrm{p}<0.001)$ was explained positively by day length $(65.1 \% ; \mathrm{p}<0.001)$ and negatively by wave height $(14.6 \% ; \mathrm{p}<0.01)$.

\section{DISCUSSION}

\section{Temporal variation in spawning patterns}

There was high seasonal variability in the fecundity of Phragmatopoma lapidosa in the Boynton Beach area. Fecundity of both intertidal and subtidal worms was high from early summer through fall and was followed by drastic decreases in late fall and early winter. Consequently, while some individual P. lapidosa can be induced to spawn year-round, spawning potential is highest during summer and early fall.

The analysis of seasonal changes in mean egg diameter also suggests summer and early fall spawning peaks. Smaller oocytes coincided with higher fecundi-
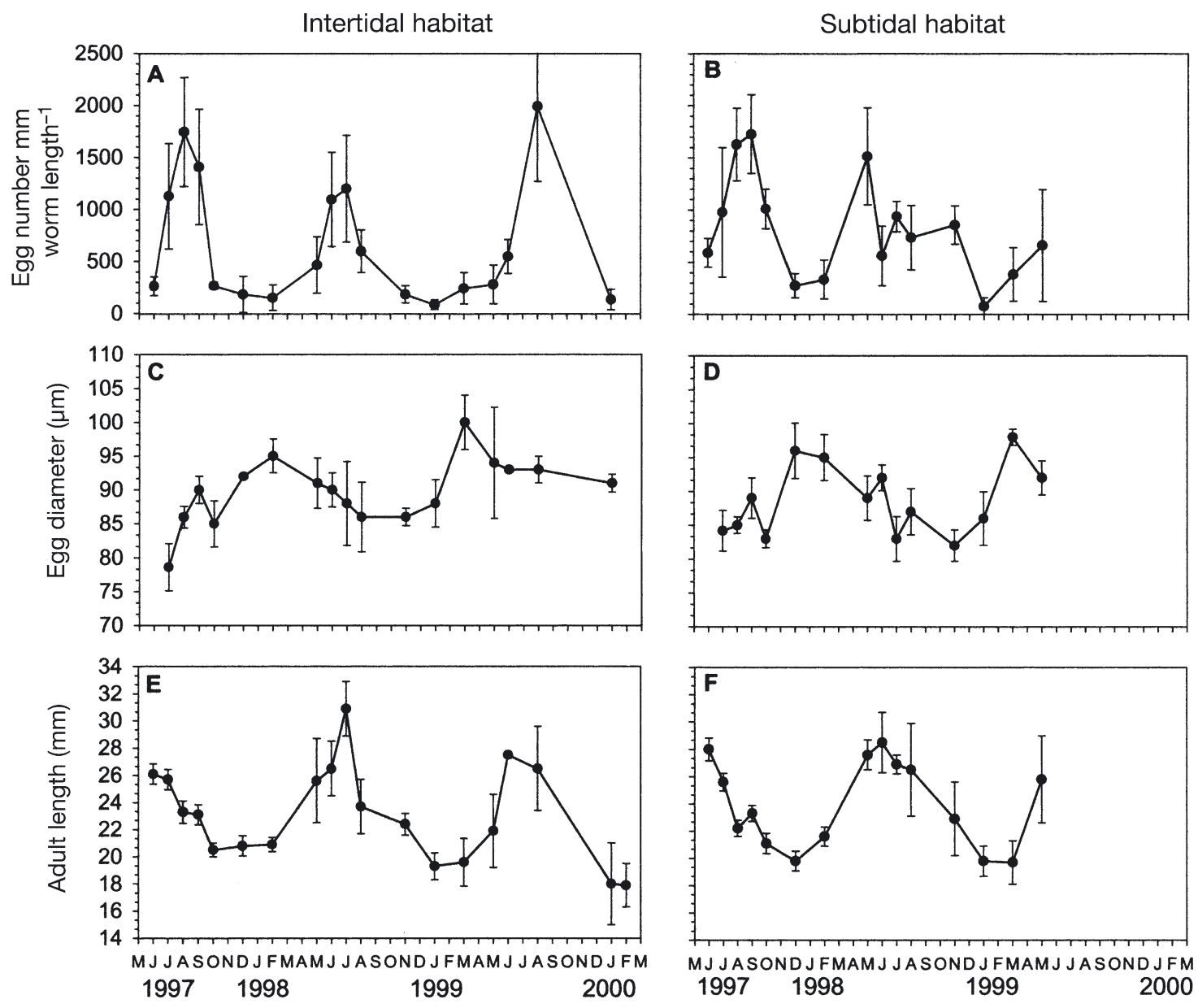

Month and Year

Fig. 4. Phragmatopoma lapidosa. Seasonal changes in mean $( \pm 1.0 \mathrm{SD})$ fecundity, egg diameter and adult length of intertidal and subtidal worms (A,B) Subtidal worms were more fecund than intertidal worms in October 1997, May 1998, November 1998 and March 1999 (Tukey pairwise probablities between habitats = 0.001, 0.004, 0.001 and 0.036 respectively). (C,D) Egg diameters were significantly larger subtidally than intertidally in month of July 1997 (Tukey pairwise probability = 0.005). (E,F) Adults were significantly larger intertidally than subtidally in July 1998 (Tukey pairwise probability $=0.002$ ). Subtidal sites were completely covered by sand after March 1999 
Table 2. Phragmatopoma lapidosa. Pearson correlation coefficients of within and between census values of fecundity and egg diameter, fecundity and adult length and egg diameter and adult length for intertidal and subtidal worms. ${ }^{*}$ Statistically significant at 0.05 level

\begin{tabular}{|c|c|c|c|c|c|c|}
\hline \multirow{2}{*}{$\begin{array}{l}\text { Comparison } \\
\text { Census date }\end{array}$} & \multicolumn{2}{|c|}{ Egg diam./Egg no. } & \multicolumn{2}{|c|}{ Egg no./Adult size } & \multicolumn{2}{|c|}{ Egg no./Adult size } \\
\hline & Intertidal & Subtidal & Intertidal & Subtidal & Intertidal & Subtidal \\
\hline \multicolumn{7}{|l|}{ Within census } \\
\hline Jun 97 & -0.341 & 0.201 & -0.104 & -0.322 & -0.441 & 0.044 \\
\hline Jul 97 & 0.041 & 0.361 & 0.256 & 0.274 & 0.281 & 0.281 \\
\hline Aug 97 & 0.033 & -0.122 & 0.144 & -0.236 & -0.079 & -0.029 \\
\hline Sep 97 & 0.145 & -0.425 & 0.049 & -0.497 & 0.091 & 0.538 \\
\hline Oct 97 & 0.387 & -0.192 & -0.080 & -0.381 & -0.182 & 0.036 \\
\hline Dec 97 & $0.491^{*}$ & -0.434 & 0.011 & -0.105 & -0.049 & -0.353 \\
\hline Feb 98 & 0.085 & -0.273 & -0.192 & 0.210 & 0.198 & -0.102 \\
\hline Mar 98 & -0.081 & -0.193 & 0.128 & 0.415 & 0.032 & -0.273 \\
\hline Jun 98 & -0.169 & -0.107 & -0.190 & -0.321 & 0.260 & 0.153 \\
\hline Jul 98 & 0.409 & 0.045 & -0.192 & -0.321 & -0.047 & 0.101 \\
\hline Aug 98 & 0.103 & -0.069 & -0.018 & 0.011 & 0.220 & -0.027 \\
\hline Nov 98 & -0.295 & 0.259 & 0.010 & -0.005 & -0.012 & 0.044 \\
\hline Jan 99 & $-0.558^{*}$ & 0.255 & $-0.518^{*}$ & -0.239 & 0.381 & -0.076 \\
\hline Mar 99 & $0.551^{*}$ & -0.007 & 0.382 & $0.534^{*}$ & $0.467^{*}$ & -0.226 \\
\hline May 99 & -0.006 & 0.373 & -0.348 & -0.338 & 0.074 & -0.272 \\
\hline Between census & -0.244 & -0.244 & $0.568^{*}$ & 0.282 & -0.222 & -0.239 \\
\hline
\end{tabular}

ties during summer and early fall, suggesting that the larger oocytes are spawned frequently during this period. It is unlikely that a decrease in mean egg size would be the result of an ontogenetic change in egg size and egg number because seasonal and withincensus correlations between egg diameter and adult size were generally not significant. Also, although eggs could be fertilized year-round in the laboratory, higher percentages were fertilized during the spring, summer and early fall (D.A. McCarthy pers. obs.). This could be because a fraction of the gametes were not mature at other times of the year.

\section{Seasonal entrainment of gametogenesis}

It is likely that both day length and sea temperature are important in the seasonal entrainment of gametogenesis for Phragmatopoma lapidosa. The importance of these environmental factors has been documented for polychaetes (Clark 1988, Chu \& Levin 1989, Giangrande 1997) and other invertebrates (see Giese \& Kanatani 1987 for a review). The multiple stepwise regression did reveal that day length was important in explaining fecundity variance for both intertidal and subtidal P. lapidosa. The proximity of habitats, combined with the very oligotrophic waters derived from the nearby Florida Current (approximately $1.6 \mathrm{~km}$ away), makes it likely that both light penetration and sea temperature are similar in the 2 habitats, thus affecting gametogenesis in similar ways.

\section{Spatial variation in spawning pattern}

Fecundity of Phragmatopoma lapidosa tended to be higher in subtidal than intertidal worms during most of the study period. The difference was most obvious

Table 3. Phragmatopoma lapidosa. Seasonal correlations of intertidal and subtidal fecundity, egg diameter and adult length means with chlorophyll $a$, sea temperature, wave height and day length. Measured and estimated chlorophyll $a$ values are from Fowey Rocks and Boynton Beach respectively. ${ }^{*}$ Statistically significant at 0.05 level ${ }^{* *}$ significant at 0.001 level

\begin{tabular}{|c|c|c|c|c|c|c|}
\hline \multirow{2}{*}{$\begin{array}{l}\text { Environmental } \\
\text { factors }\end{array}$} & \multicolumn{2}{|c|}{ Fecundity } & \multicolumn{2}{|c|}{$\longrightarrow$ Egg diam. } & \multicolumn{2}{|c|}{ Adult length } \\
\hline & Intertidal & Subtidal & Intertidal & Subtidal & Intertidal & Subtidal \\
\hline Day length & $0.610^{* *}$ & 0.430 & -0.349 & -0.439 & $0.783^{* *}$ & $0.822^{* *}$ \\
\hline Sea temperature & 0.427 & 0.433 & $-0.639^{*}$ & $-0.728^{* *}$ & 0.196 & 0.140 \\
\hline \multicolumn{7}{|l|}{ Chlorophyll a } \\
\hline (measured) & -0.219 & -0.445 & 0.080 & 0.180 & -0.496 & -0.378 \\
\hline (estimated) & -0.012 & -0.241 & 0.396 & 0.334 & 0.068 & -0.076 \\
\hline Wave height & $-0.672^{* *}$ & -0.394 & 0.399 & 0.420 & $-0.579^{* *}$ & -0.505 \\
\hline
\end{tabular}


from fall through spring, with intertidal and subtidal fecundities becoming virtually equal in summer. While habitat-specific differences in age could be responsible for the observed fecundity trends, these trends could also result from differences in food availability and/or the frequency of spawning cues between the 2 habitats.

\section{Habitat-specific differences in size or age}

Given the absence of a significant size difference between intertidal and subtidal worms, it is unlikely that between-habitat differences in fecundity were size-related. No significant difference in size occurred between intertidal and subtidal worms. Further, the majority of within-census correlations between egg number and adult length were not significant.

The observation that juveniles essentially replaced established adults in both habitats supports the idea that all worms were similar in age. There were cyclical changes in the sizes of both intertidal and subtidal worms (Fig. 4E,F) that corresponded with fall recruitment peaks. Sometimes unavoidable delays in sampling occurred in the fall because of storm activity. During these periods, newly settled recruits grew tubes so quickly ( $0.42 \mathrm{~mm} \mathrm{~h}^{-1}$ in the laboratory) that juvenile tubes rapidly became indistinguishable from those of established adults. It was only apparent that the worms were smaller when tubes were dissected in the laboratory. The combined observations of cyclical size changes and massive recruitment in both habitats suggest that individuals of Phragmatopoma lapidosa spawn gametes for a single season before dying. This observation is in line with Kirtley's (1966) prediction that they have a lifespan of approximately 1 to 2 yr.

\section{Food availability}

Habitat-specific differences in food concentration or duration of feeding time could explain the observed fecundity patterns. Studies have demonstrated relationships between food quantity or quality and reproductive output in spionid polychaetes (Levin 1986, Grémare et al. 1989, Levin 1991, Qian \& Chia 1991) as well as other invertebrates (McKillup \& Butler 1979, George et al. 1990, George 1994). For example, Walker \& Heffernan (1994) observed differences in time to spawning and gonad index with relation to level of tidal exposure of the northern quahog Mercenaria mercenaria. Differences in immersion times between intertidal and subtidal Phragmatopoma lapidosa could affect the amount of energy available for reproduction. However, if this were the only variable responsible for the apparent difference in rate of egg production between intertidal and subtidal P. lapidosa, fecundity would be expected to covary in the 2 habitats. Additionally, if food availability were solely responsible, it would be expected that seasonal correlations between fecundity and chlorophyll $a$ would be significant. They were not. While a non-significant correlation between fecundity and chlorophyll a does not negate the importance of seasonal food availability for reproduction, it does imply that other environmental factors that vary between habitats have an effect on fecundity.

\section{Disturbance}

Differences in wave energy that affect spawning provide the most likely explanation for the observed differences in fecundity patterns between intertidal and subtidal Phragmatopoma lapidosa. During this study, both intertidal and subtidal hard-bottom habitats with P. lapidosa reefs were affected by waveinduced disturbance. Wave-induced disturbance was most severe during the hurricane season in late summer and early fall, and to a lesser extent during the winter. Wave action damaged worm reefs in both habitats by either breaking them apart and/or smothering them with sand. Intertidal worm reefs were more obviously affected by physical destruction during periods of increased wave activity than subtidal reefs. This is because intertidal reefs were exposed to the full force of waves crashing on them at low tide. In contrast, subtidal worms were always at least a few meters deep, so they were not exposed to the same level of destructive force as intertidal worms. Numerous intertidal colonies displayed cracks caused by the force of crashing waves. In addition, sand movement was high during storms and scoured intertidal colonies. No comparable cracks were observed in subtidal reefs, but sandscouring did occur. These observations suggest that sublethal disturbances might be somewhat more frequent and unpredictable intertidally than subtidally. Such differences in sublethal disturbance between intertidal and subtidal habitats are likely to affect adult energy investment in reproduction by diverting energy to regeneration of body parts. However, as the individual worms used in our study appeared to be undamaged and were of similar sizes, the effects of sublethal disturbance on the energy available for reproduction may possibly not be important in explaining the observed fecundity trends.

Disturbance is very likely to contribute to the observed differences in fecundity between worms from the 2 habitats by affecting the frequency in spawning. When spawning occurs, eggs free in the coelomic cavities of a female of Phragmatopoma lapi- 
dosa will be spawned; eggs still attached and developing in gonads will not be released. Ultrastructural research has revealed that $P$. lapidosa has vitellogenic mechanisms that produce mature eggs in just a few days (Eckelbarger 1979). Individual worms that have been spawning more frequently may have produced fewer new cohorts and thus appear to have lower numbers of eggs. In contrast, worms that have been holding gametes because they have not received the cue to spawn would appear to have higher fecundities.

\section{Summary}

We found that seasonal spawning in Phragmatopoma lapidosa was very tightly linked to day length and wave activity. We also found that intertidal worms generally spawned more often than subtidal worms. Both observed patterns could simply reflect food availability; however, the evidence suggests that surviving worm colonies are likely to have spawned gametes in response to sublethal disturbance caused by waves, and that intertidal worms probably do so more often than subtidal worms. These spawning differences are indeed expected, because the levels of sublethal and lethal disturbances which stimulate spawning are higher intertidally than subtidally (McCarthy 2001). The ability of $P$. lapidosa to produce eggs rapidly may allow it to respond plastically to varying intensities of disturbance, and thereby enhance the chance that larval recruitment will occur when space is available for colonization.

Acknowledgements. We thank Tracy Griffin, Sandra Brooke, Mike Fulmer and Jimmy Nelson for field assistance. We thank Thomas Stach for helpful suggestions on the manuscript. We also thank Joe Boyer and Frank Muller-Karger for use of their chlorophyll a data. This research was funded by the National Science Foundation (OCE-9633784) and is Harbor Branch contribution number 1505 and Smithsonian Marine Station at Fort Pierce contribution number 565.

\section{LITERATURE CITED}

Barry JP (1989) Reproductive response of a marine annelid to winter storms: an analog to fire adaptation in plants? Mar Ecol Prog Ser 54:99-107

Cardenas EB, Aranda DA (2000) A review of reproductive patterns of bivalve mollusks from Mexico. Bull Mar Sci 66:13-27

Chu JW, Levin LA (1989) Photoperiod and temperature regulation of growth and reproduction in Strebliospio benedicti (Polychaeta: Spionida). Invertebr Reprod Dev 15:131-142

Clark S (1988) A two-phase photoperiodic response controlling the annual gametogenic cycle in Harmothoe imbricata (L.) (Polychaeta: Polynoidae). Invertebr Reprod Dev 14:245-266
Connell JH, Keough MJ (1985) Disturbance and patch dynamics of subtidal marine animals on hard substrata. In: Pickett STA, White PS (eds) The ecology of natural disturbance and patch dynamics. Academic Press, New York, p 125-151

Eckelbarger KJ (1976) Larval development and population aspects of the reef-building polychaete Phragmatopoma lapidosa from the east coast of Florida. Bull Mar Sci 26: $117-132$

Eckelbarger KJ (1979) Ultrastructural evidence for both autosynthetic and heterosynthetic yolk formation in the oocytes of an annelid (Phragmatopoma lapidosa: Polychaeta). Tissue Cell 11:425-443

George SB (1994) Population differences in maternal size and offspring quality for Leptasterias epichlora (Brandt) (Echinodermata: Echinoidea). J Exp Mar Biol Ecol 175: 121-131

George SB, Cellario C, Fenaux L (1990) Population differences in egg quality of Arbacia lixula (Echinodermata: Echinoidea): proximate composition of eggs and larval development. J Exp Mar Biol Ecol 141:107-118

Giangrande A (1997) Polychaete reproductive patterns, life cycles and life histories: an overview. Oceanogr Mar Biol Annu Rev 35:323-386

Giese AC, Kanatani H (1987) Maturation and spawning. In: Giese AC, Pearse JS, Pearse VB (eds) Reproduction of marine invertebrates, IX. Blackwell Scientific Publishers, Palo Alto, CA, p 252-313

Grémare A, Marsh AG, Tenore KR (1989) Fecundity and energy partitioning in Capitella capitata type I (Annelida: Polychaeta). Mar Biol 100:365-371

Hartman O (1944) Polychaetous annelids from California. Part IV. Paraonidae, Magelonidae, Longosomidae, Ctenodrilidae, and Sabellariidae. Allan Hancock Pac Exped 10: 311-389

Hildrew AG, Raffaelli DG, Giller PS (1994) Aquatic ecology: scale, pattern and processes. Blackwell Scientific Publications, Oxford

Hill SD, Grassle JP (1981) Caudal regeneration as a measure of senescense in Capitella sp. I. (Polychaeta). Biol Bull 161: 327

Hill SD, Grassle JP, Mills SW (1982) Regeneration and maturation in two sympatric Capitella (Polychaeta) sibling species. Biol Bull 163:366

Jensen RA (1986) Factors affecting the settlement, metamorphosis and distribution of larvae of the marine polychaete Phragmatopoma californica (Fewkes). PhD thesis, University of California, Santa Barbara, CA

Jokiel PL (1985) Lunar periodicity of planula release in the reef coral Pocillopora damicornis in relation to various environmental factors. Proc 5th Int Coral Reef Congr 4: 307-312

Kirtley DW (1966) Intertidal reefs of Sabellariidae (Annelida Polychaeta) along the coasts of Florida. MSc thesis, Florida State University, Tallahassee, FL

Kirtley DW (1994) A review and taxonomic revision of the family Sabellariidae Johnston, 1865 (Annelida; Polychaeta). Sabecon Press, Vero Beach, FL

Kojis BL, Quinn NJ (1984) Seasonal and depth variation in fecundity of Acropora palifera at two reefs in Papua New Guinea. Coral Reefs 3:165-172

Lawrence JM, Vasquez J (1996) The effect of sublethal predation on the biology of echinoderms. Oceanol Acta 19: 431-440

Levin LA (1986) Effects of enrichment on reproduction in the opportunistic polychaete Streblospio benedicti (Webster): a mesocosm study. Biol Bull 171:143-160 
Levin LA (1991) Multiple patterns of development in Streblospio benedicti Webster (Spionidae) from three coasts of North America. Biol Bull 166:494-508

Main MB, Nelson WG (1988) Tolerance of the sabellariid polychaete Phragmatopoma lapidosa Kinberg to burial, turbidity and hydrogen sulfide. Mar Environ Res 26:39-55

McCarthy DA (2001) Life-history patterns and the role of disturbance in intertidal and subtidal populations of the polychaete Phragmatopoma lapidosa lapidosa (Kinberg, 1867) in the tropical Western Atlantic. PhD thesis, King's College, University of London

McKillup SC, Butler AJ (1979) Modification of egg production and packaging in response to food availability by Nassarius pauperatus. Oecologia 43:221-231

Osman RW (1977) The establishment and development of a marine epifaunal community. Ecol Monogr 47:37-63

Pawlik JR (1988) Larval settlement and metamorphosis sabellariid polychaetes, with special reference to Phragmatopoma lapidosa, a reef-building species, and Sabellaria floridensis, a non-gregarious species. Bull Mar Sci 43: 41-60

Pickett STA, White PS (1985) The ecology of natural disturbance and patch dynamics. Academic Press, New York

Qian PY, Chia FS (1991) Fecundity and egg size are mediated by food quality in the polychaete worm Capitella sp. J Exp Mar Biol Ecol 148:11-25

Rinkevich B, Loya Y (1979) The reproduction of the Red Sea coral Stylophora pistillata. II. Synchronization in breeding and seasonality of planulae shedding. Mar Ecol Prog Ser $1: 145-152$

Sousa WP (1984) The role of disturbance in natural communities. Annu Rev Ecol Syst 15:353-391

Swarbrick SL (1984) Disturbance, recruitment and competi-

Editorial responsibility: Otto Kinne (Editor),

Oldendorf/Luhe, Germany tion in a marine invertebrate community. PhD thesis, University of California, Santa Barbara, CA

SYSTAT (1992) SYSTAT for Windows: Statistics, Version 5. SYSTAT, Evanston, IL

Szmant AM, Gassman NJ (1990) The effects of prolonged bleaching on the tissue biomass and reproduction of the reef coral Montastrea annularis. Coral Reefs 8:217-224

Taylor PR, Littler MM (1982) The roles of compensatory mortality, physical disturbance, and substrate retention in the development and organization of a sand-influenced, rocky-intertidal community. Ecology 63:135-146

Tomascik T, Sander F (1987) Effects of eutrophication on reefbuilding corals. II. Structure of scleractinian coral communities on fringing reefs, Barbados, West Indies. Mar Biol 94:53-75

Van Veghel MLJ, Bak RPM (1993) Intraspecific variation of a dominant Caribbean reef building coral Montastrea annularis: genetic, behavioral and morphometric aspects. Mar Ecol Prog Ser 92:255-265

Walker RL, Heffernan PB (1994) Temporal and spatial effects of tidal exposure on the gametogenic cycle of the northern quahog, Mercenaria mercenaria (Linnaeus, 1758), in coastal Georgia. J Shellfish Res 13:479-486

Ward S (1995) The effect of damage on the growth, reproduction and storage of lipids in the scleractinian coral Pocillopora damicornis (Linnaeus). J Exp Mar Biol Ecol 187: 193-206

Wilcox D, Dave B, McDavid D, Greer D (1995) UTHSCSA image tool for Windows. Version 1.27. University of Texas Health Science Center, San Antonio, TX

Zajac RN (1985) The effects of sublethal predation on reproduction in the spionid polychaete Polydora ligni (Webster). J Exp Mar Biol Ecol 88:1-19

Submitted: May 7, 2002; Accepted: March 11, 2003

Proofs received from author(s): July 3, 2003 